\title{
The Relevance of Roman Law: A Look at its Roles and Ideologies
}

A importância do direito romano: um olhar sobre o seu papel e as suas ideologias

La pertinence du droit romain: un regard sur ses rôles et ses idéologies

\section{Miklós Könczöl}

\section{OpenEdition}

\section{Journals}

Electronic version

URL: http://journals.openedition.org/rccs/6597

DOI: $10.4000 /$ rccs. 6597

ISSN: 2182-7435

\section{Publisher}

Centro de Estudos Sociais da Universidade de Coimbra

\section{Printed version}

Date of publication: 1 May 2017

Number of pages: 99-114

ISSN: 0254-1106

\section{Electronic reference}

Miklós Könczöl, «The Relevance of Roman Law: A Look at its Roles and Ideologies », Revista Crítica de Ciências Sociais [Online], 112 | 2017, Online since 15 May 2017, connection on 10 December 2020.

URL : http://journals.openedition.org/rccs/6597 ; DOI : https://doi.org/10.4000/rccs.6597 


\section{MIKLÓS KÖNCZÖL}

\section{The Relevance of Roman Law: A Look at its Roles and Ideologies*}

The paper examines legal historians' discourses concerning the interpretation of Roman legal sources. It does so by analysing two examples of scholarly debates: one on the use of Roman law as an atemporal legal doctrine, and one in which Roman law appears as a historical manifestation of natural law. The focus is on the different uses of the concept of 'ideology' and the possible roles of Roman law in legal education. It is argued that the concept of identity can meaningfully contribute to our understanding of these debates as well as to the study of Roman law in general.

Keywords: identity; ideology; legal profession; natural law; Roman law.

\section{Introduction}

Law is, in more than one way, linked to the past, and as Aristotle instructs us, legal decisions are concerned with matters that have already taken place. Past actions may also contribute to establishing probabilities or to determining an edifying punishment. History itself is at times legislated upon, making 'official' narratives the basis for further decisions, sometimes even protected by means of legitimate violence. Yet law has its own history - or histories, if one recognises the competing reconstructions of past legal settings. This paper will discuss the latter, legal history, and more particularly, the ways in which law is reconstructed on the basis of often fragmentary sources, and in which people make use ${ }^{1}$ of those reconstructions.

* An early version of this article was presented at the Congrès Mondial ISA/RCSL 2013 "Sociologie du droit et action politique" in Toulouse. The author would like to thank the anonymous reviewers for their valuable comments and suggestions.

${ }^{1}$ See Costa (2007: 256) quoting Umberto Eco's distinction of 'use' and 'interpretation' (cf. Eco, 1990: 32-33), and Tuori (2007: 10), arguing that "[f]or most of its history the purpose of legal history has been something more than simply writing history for its own sake: history served to legitimise current policies and acted as a storehouse of examples." On the differences within 'Romanism', see Lombardi Vallauri (1985: 341-342), who distinguishes at least three traditions (apart from Justinian's 'Christian-Byzantine' one): a 'mystical-universalist' conception, appearing in the Holy Roman Empire and the Roman Church in the early Middle Ages, the 'republican-revolutionary' Romanism of the French Revolution, and, perhaps most importantly, the 'technical-universalist' one, beginning with the Glossators and the Commentators. 
The two examples of scholarly discourse to be addressed in the present work come from the field of Roman law. While they are concerned with the ways in which specific Roman legal institutions are reconstructed, questions having a political dimension have been raised in both cases. Thus, when one examines legal history, at issue is not only the scholarly method itself but also what one does with that reconstruction.

Before taking up specific examples, a brief mention should be made here of the main currents of juristic studies of Roman law, each representing a different approach to the possible lessons of these studies. The first and perhaps most 'lawyerly' approach, and certainly the most influential one, at least in Europe, is what is often termed neo-Pandectism. ${ }^{2}$ It focuses on the conceptual system of Roman law, ${ }^{3}$ and justifies the study of the 'civilian tradition' with the usefulness of those concepts for modern-day efforts of legal harmonisation. ${ }^{4}$ A related and similarly long-established way of using Roman law is the search for timeless moral and legal values underlying its institutions. ${ }^{5}$ From this perspective, Roman law and society may be valued for offering a particularly clear view of the very foundations of any human society. ${ }^{6}$ Thirdly, scholars have looked at Roman legal institutions as social constructs created in a specific historical context. Here then, differences within the 'tradition' become important, which also helps one to question the timeless necessity of any legal institution. ${ }^{7}$ While the scholarly debates discussed below highlight the differences between these approaches, they also show how they may enter into dialogue with one another.

Dialogue, of course, may seem an euphemism here: the texts considered in the following sections contain harsh criticism of certain scholarly approaches considered inadequate (or even dishonest). As mentioned above, the debate

\footnotetext{
${ }^{2}$ Perhaps best exemplified in recent scholarship by the work of Reinhard Zimmermann. See esp. Zimmermann (1996a), who claims that the study of Roman law is directly relevant for the understanding of modern Western law.

3 And more importantly, considers the concepts and institutions of Roman law as parts of a system.

${ }^{4}$ See, e.g., Zimmermann and Whittaker (2000), the first volume-length output of 'The Common Core of European Private Law' project, including a chapter on good faith in Roman law (Schermaier, 2000).

5 For a brief historical overview and critical assessment of both approaches, see Costa (2007), who claims that instead of looking for a uniform tradition (which has apparently never existed), it is "[r]eflecting on the contradictory multiplicity of traditions" that "can contribute to extend the spectrum of possibilities: it can help us contain the tyranny of the present, attribute greater value to differences and, for this reason, expand the domain of the conceivable" (ibidem: 269).

${ }^{6}$ For recent examples of this approach, see El Beheiri (2012) and Deli (2015), who both look at examples of the Roman jurists' reliance on extra- or pre-legal values, albeit from different perspectives.

7 The work of Yan Thomas (2011) and Aldo Schiavone (2005) may be mentioned as representative of that current.
} 
goes beyond the competing historical reconstructions, with the authors reflecting not only on the ways, but also the purpose of these reconstructions. The two are connected by the concept of ideology, and the similarities and differences between the use of that concept in each case will be highlighted.

The first example will be a set of papers with the overarching argument that certain Romanists are mistaken as they try to find evidence for the presence of the legal profession in Roman sources, while denying or downplaying the important connection between law and rhetoric. In the second example, it is the natural-law approach to Roman sources that is challenged. Trying to discover one's own moral principles in the sources, it is argued, serves to conceal the important fact that Romans were able to adapt their legal institutions to changing social realities.

The choice of examples was mainly motivated by the more or less explicit reference to ideologies. Yet while working on them, it became apparent that they also raise further questions relevant to the social sciences in general, and the relationship between law and culture in particular. One of these is related to relevance. All participants of the discourses examined seem to presuppose that there is a lesson: that in some way we can learn from a normative system that is no longer valid. Relevance, in turn, is backed by various conceptions of identity. It is a combination of two kinds of identity, cultural and professional, that induces us to learn from the Romans.

\section{Roman Law as Legal Doctrine}

Dutch legal historians Jan Willem Tellegen and Olga Tellegen-Couperus devoted several articles to rectifying claims made by German Romanists in the $19^{\text {th }}$ century concerning specific legal institutions on the one hand, and the early professionalisation of Roman jurists on the other (see, e.g., Tellegen, 1983; Tellegen and Tellegen-Couperus, 2000). Some of these articles deal with the use of Cicero's speeches and theoretical writings as sources for Roman legal history. In one of these, Tellegen looks at Cicero's speech Pro Caecina, and the way it has been (mis)read by the celebrated Romanist, Friedrich Carl von Savigny, father of the 'Historical School', and those following him (Tellegen, 1996).

In the speech, Cicero argued that his client, Aulus Caecina, was unlawfully prevented from entering an estate by a certain Aebutius and his armed men. Caecina claimed that he had inherited the estate from the previous possessor, Caesennia, who had a life interest on it. Aebutius challenged Caecina's claim, and they agreed to go before the court to settle the dispute. According to Roman procedure, that would require that Caecina first be 'expelled' by Aebutius from the land (vis ac deductio moribus). Aebutius, however, 
did not let Caecina enter the property, apparently in order to avoid the judicial procedure. In his speech, Cicero had to respond to a series of objections made by Aebutius' counsel: (1) Caecina could not have been 'expelled' as he did not enter the estate; (2) Aebutius did not use 'force' to prevent him from entering; (3) the injunction Caecina applied for requires possession but he was not the possessor; (4) not being the owner, Caecina did not have any right to possession either (cf. Grose Hodge, 1927: 86-87).

In his early work Das Recht des Besitzes, Savigny reconstructed Cicero's argument as follows: as neither party could prove ownership, they should have focused on the question of rightful possession. Yet Caecina would not have been able to prove that either. What he applied for was an interdictum de vi armata, and Cicero emphasised the fact that armed force had indeed been used against his client, trying to downplay the importance of the question of possession. That, in Savigny's view, was the job of an orator, yet that also means that Cicero's speech is not a reliable historical source (Savigny, 1803: 368-369).

According to Tellegen, this was a clear misrepresentation of Cicero's original line of thought (Tellegen, 1996: 103-106). While it was beyond doubt that Caecina could prove no possession in the legal sense, Cicero did not in fact resort to rhetorical trickery because he did not have to. His argument, according to which the interdictum de vi armata was meant to offer redress against the use of armed force, and thus the claimant did not have to prove that he had been in possession of the land in dispute, was based on a possible interpretation of the formula, and not invented to mislead the judges.

Tellegen argues that Savigny's views were shaped by two factors in particular. First, he conceived of Roman law as a 'system', i.e. an organised body of rules, which did not allow for gaps or contradictions. Second, he assumed that already in Cicero's time there was a clear distinction between lawyers and advocates, iurisprudentes and oratores, people versed in law and rhetoric, respectively. As Tellegen points out, however, neither of these claims seems to be supported by the extant sources.

As for the 'system' of Roman law, it clearly did not exist back in Cicero's age, the first century BC. What Cicero had to work with was a few laws and a series of judicial decisions. Savigny, however, seems to be looking for, and projecting back, some sort of an unwritten civil code, as well as assuming that Roman legal institutions did not change over time. What follows from that is his presumption, according to which if something did not exist in the Codex Iustinianus, then it cannot have existed earlier either: if there was no legal protection for a non-possessor in the Codex, then it must be Cicero's own invention. 
While that 'timelessness' of Roman law is rather interesting in itself, ${ }^{8}$ what is of greater importance here is the explanation Tellegen offers for it. In his view, Savigny's research into Roman legal institutions had been motivated by the aim to find a model that could be emulated by the emerging German law of the post-Napoleonian era. ${ }^{9}$ No wonder, then, that the clearly outlined institutions of the Codex seemed more suitable for him than the controversial legal situation reflected by Cicero's writings.

Tellegen highlights another feature of Savigny's work, the dichotomy of advocates and jurists. While this is not made explicit by Savigny, it is telling, he claims, that Cicero's speech appears among the non-legal sources. ${ }^{10}$ More importantly for Tellegen, Savigny's dichotomy stands at the beginning of a tradition, ${ }^{11}$ one that tends to discount Cicero's work as a historical source, classifying him instead as an orator as opposed to one of the iurisprudentes. ${ }^{12}$

It is the same tradition that is in the focus of further criticism in a later article on the interpretation of the sources relevant for the reconstruction of a famous Roman legal case, the causa Curiana (Tellegen and Tellegen-Couperus, 2000). In a further swipe at scholars who accept the opposition of orators and legal experts, ${ }^{13}$ Tellegen and Tellegen-Couperus wonder whether such a position is mere anachronism or whether it can be classified as falsification. Stating that falsification requires the intent to deceive as a conceptual element, they concede that

[i]t seems highly unlikely that we will be able to prove that the Romanists in question constructed their interpretations with the intent to deceive. Here, it is not a question of a single frustrated archaeologist, as in the case of the fibula Praenestina $;{ }^{14}$ these

\footnotetext{
${ }^{8}$ Tellegen argues that Savigny actually comes quite close to some kind of a natural-law conception (Tellegen, 1996: 104), one that would be at odds with his well-known idea of organic development. ${ }^{9}$ For a thorough examination of $19^{\text {th }}$-century German Romanists' political agenda, see Whitman (1990). ${ }^{10}$ This is certainly not the case in the third edition (1818) or the later ones, in which Cicero's writings are listed among the 'pre-Iustiniani legal sources' (vorjustinianische Rechtsquellen). The first two editions (1803 and 1806), however, have no index of sources. In the main text, the Pro Caecina appears among the sources, followed by the Digest, the Codex Iustiniani, and the Codex Theodosiani at the beginning of the section on the interdicta de vi (Savigny, 1803: 364).

${ }_{11}$ Represented, e.g., by Schulz (1936; 1946), Nicosia (1965), Stroh (1975). On the image of Q. Mucius Scaevola, Cicero's opponent in the case, as the 'founding father' of legal science, see the detailed discussion of Tuori (2007: 21-69).

${ }^{12}$ In an earlier article, Tellegen traced that back to Mommsen (1933, cf. Tellegen, 1983: 294, with no. 2)

${ }^{13}$ In addition to Schulz, the authors whose views are challenged are, inter alia, Wieacker (1967) and Manthe (1997).

14 The brooch called fibula Praenestina, discovered in the late $19^{\text {th }}$ century, bears an inscription that is usually regarded as the earliest text in Old Latin. Later, however, suspicion was raised that the text was actually a forgery. Recent research seems to support the authenticity of both the fibula and its inscription (see Maras, 2012).
} 
Romanists formed a select body of lawyers with established reputations. However, we will try to demonstrate that separating law and rhetoric, in fact, verges on falsification, firstly because the authors had, or thought they had, the opportunity and good reason to uphold this separation, and secondly because they must have known that the separation should be considered as scientifically outdated. (Tellegen and Tellegen-Couperus, 2000: 187-188)

The explanation they offer is as follows. After the German Civil Code entered into force in 1900, Roman law was no longer part of the German legal system. Roman law as a subject, however, has held its place in the law curriculum until quite recently. Rather than turning to historical methods proper, Romanists continued to view Roman law as a 'system' in the sense of legal doctrine, emphasising its importance for legal education, ${ }^{15}$ and, more recently, for the shaping of a uniform European civil law (cf., for the latter, Zimmermann, 1996b). The authors then conclude by noting that "[Romanists] give the impression that their staunch support of the distinction between law and rhetoric stems from the desire to safeguard their position in their respective law faculties" (Tellegen and Tellegen-Couperus, 2000: 188).

The Tellegens' argument would certainly deserve more attention, particularly since the connection between the Romanists' doctrinal attitude and the separation of law and rhetoric seems less than compelling. ${ }^{16}$ Yet what is more relevant for the present discussion is their description of what could be termed the 'Romanist ideology'. While they do not use the word, their characterisation of the Romanists' moves corresponds to Marx's and Engels' concept of 'ideology', used primarily in the sense of 'false consciousness' (cf. Pines, 1993: esp. ch. 4). Romanists, on the above account, established and maintained an image of an atemporal 'Roman law', which they tried to sell to society as the legal system par excellence, an object of knowledge that was best situated to introduce law students to 'lawyerly thinking'. Yet that image was an epistemologically false one, and it only served to legitimise the Romanists' presence in law schools. Considered from that angle, the opposition of law and rhetoric grows far beyond what could be reasonably accounted for as a mere academic mistake, to which all scholars are arguably entitled, and is brought to a political dimension. While the

\footnotetext{
${ }^{15}$ See, however, an 1858 talk by the famous Pandectist, Bernhard Windscheid, explaining that Roman law, once ceasing to be valid law, would represent Antiquity, and have an aesthetic-educational value (apud Whitman, 1990: 228).

${ }_{16}$ To mention just one example, Frier (1985) disagrees with Nicosia (1965) and Stroh (1975), who argued for Cicero's misrepresentation of the legal issue, but thinks that the Pro Caecina actually signals the transition from the orators' court to that of the lawyers.
} 
authors compare the situation of Romanists to that of the scholar allegedly responsible for the fibula Praenestina scandal, the former case has had a much more far-reaching impact on the place of Roman law within the education of further lawyers. Interestingly, however, Tellegen and Tellegen-Couperus do not draw any conclusion as to the justification for the study of Roman law. They merely remark that the Romanists' attempt at preserving their positions was apparently unsuccessful, given the recent disappearance of Roman law from the list of compulsory subjects in several countries (Tellegen and Tellegen-Couperus, 2000: 188).

\section{Roman Law as Legal Philosophy}

In the previous section, we have seen, behind the issues of textual interpretation, an example for the conceptualisation of Roman law as a model legal system with a crystallised doctrinal framework. In the next example, Roman law will play a somewhat similar and yet fundamentally different role, departing from the field of legal doctrine to enter that of legal philosophy.

Since Cicero's De legibus at least, a special link between natural law and the laws of the Roman republic has often been established in literature. For Cicero, that was quite a natural move. As one scholar recently noted, "Cicero models his laws on the precepts used by the Stoics to state imperfect duties. He uses Roman laws as a way of filling in the content of these duties" (Asmis, 2008: 3). Later authors, however, sometimes look at Roman law, and particularly its manifestation in Justinian's Corpus iuris civilis as a legal order that is closer to the natural order of things than any of the modern legal systems.

A recent example for the latter approach is Wolfgang Waldstein's (2010) book, Written into the Heart: Natural Law as the Foundation of Human Society (Ins Herz geschrieben: das Naturrecht als Fundament einer menschlichen Gesellschaft). Waldstein does not, however, argue for the superiority of Roman law in itself. Roman law for him is important for two reasons. First, as an example that proves the traditional naturalist claim, according to which human beings are capable of realising the existence of natural law without divine revelation or even belief in God the Creator (see e.g. Waldstein, 2010: 46; see also Waldstein, 2012: 181-185). Second, Waldstein is interested in the continuous 'natural-law practice' (Rechtspraxis), i.e. an empirical reality reflecting the knowledge of natural law, ${ }^{17}$ which characterises

17 Waldstein's preoccupation with practice may be explained with the fact that most of his arguments are directed against Hans Kelsen's positivist views (cf. e.g. Kelsen, 1963) and the charge of 'Naturalist Fallacy' in particular (see esp. Waldstein, 2010: 15-21; Waldstein, 2012: 178-179). 
European legal history, rather than natural-law theories based on philosophical speculation. Given that it was the Roman jurists who made the first explicit references to ius naturale, their work is necessarily at the heart of Waldstein's arguments.

One of these arguments, according to which the Roman law of marriage defined the institution as the union of male and female, was based on natural law (Waldstein, 2010: ch. 6) and has been recently criticised by Jakub Urbanik (2014). What Urbanik challenges is not the Roman definition of marriage, but Waldstein's claims that, on the one hand, the Roman jurists considered marriage to be based on natural law, and, on the other, that Roman marriage should therefore serve as a model for any modern legal regulation. These two arguments shall be addressed, each in turn.

Looking at the passages used by Waldstein to ground his conclusion, Urbanik offers a different interpretation as to the source of the law of marriage. Taking up Ulpian's dictum at the beginning of the Digest (D. 1.1.1.3), he points out that the sentence "[f]rom it [sc. natural law] comes the union of male and female, which we call marriage, procreation of children, and their rearing", refers to 'marriage' as a specific Roman concept, and not something that is already present in nature (Urbanik, 2014: 948). In an earlier passage quoted from Gaius (1.158), we find that "a decision under civil law may destroy civil rights but not natural ones (iura naturalia)". While Waldstein regards that as an early (pre-Christian) affirmation of the binding force of natural law, Urbanik notes that the term 'natural rights' refers to those resulting from the blood relationship between parents and children, which "can obviously not be altered by any human decree" (Urbanik, 2014: 949). The same disagreement can be observed in the interpretation of ius naturale in a passage from Paulus (D. 23.2.14.2), where the jurist states that "in entering into marriage one should contemplate natural law and modesty (pudor): and it is contrary to modesty to marry one's daughter". Here, Urbanik emphasises that it is not natural law but modesty that forbids marriage between a woman and her father even in cases where there is no presumption of fatherhood, i.e., where the natural father is not 'father' in the legal sense (Urbanik, 2014: 949-950). A final passage is one from Modestinus (D. 23.2.1), and defines marriage as "a joining of husband and wife, partnership of fates in all aspects of life, a communication under divine and human law (divini et humani iuris)". In interpreting that fragment, Waldstein identifies ius divinum with ius naturale, linking it to a passage of Justinian's Institutions (1.2.11). Urbanik, in turn, thinks that Modestinus' 'divine law' cannot be the same as Ulpian's 'natural law', and argues for a Stoic conception of nature in the case of Ulpian, which would in that case be a non-moral one, similarly to that of Gaius (Urbanik, 2014: 950-955). 
In a second step, Urbanik expresses some doubts as to the usefulness of looking at Roman law as a model for morally founded legal development. He points out that it is sometimes the social exclusiveness of Roman marriage that has been emphasised by Romanists who tried to establish a link between the Romans and their own age, ${ }^{18}$ while others highlighted its dissolubility. ${ }^{19}$ But whatever the actual character of the Roman institution, Urbanik also makes two further caveats: one against the confusion of scholarly roles, and another against the (ab)use of Roman law for justification. The first one comes from Tomasz Giaro, who summarises the lessons Romanists can learn from previous scholarship on Roman marriage as follows:

One should not confuse the problems of the Romans with those of Romanists, of historiography and legal policy. And one should never mistake the Romanist's craft with that of the legal philosopher, the laudator temporis acti, or even with the prophet. (Giaro, 2005: 110, apud Urbanik, 2014: 958)

The second caveat concerns the teaching of Roman law in particular. If one seeks to support one's "modern ideological choice with reference to Roman legal reasoning, no matter whether the reconstruction be accurate or not, puts the teaching of Roman law at risk", since the latter will be regarded by the general public (and political decision-makers) as a 'fifth column' of a specific ideology they may find dangerous (Urbanik, 2014: 958-959).

By way of conclusion, Urbanik also mentions two fields in which Roman law can usefully contribute to the education of future lawyers. The first one is developing legal skills, and further conveying the insight that law needs to be flexible if it is to serve society. That latter is linked to the second field, where Roman law provides a historical example, that of the ius honorarium. The decisions of Roman praetores have, in many respect, adapted civil law to changing social situations, and can be therefore regarded as the predecessors of modern judicial activism, a way of developing law ahead of legislation (Urbanik, 2014: 959-960).

Since the role of ideologies is made explicit by Urbanik, it is especially important to note the difference between his usage of the concept and that

\footnotetext{
18 The two examples, taken from Giaro (2005), are Jhering (1894) and Wieacker (1937a, 1937b), the latter praising "the re-emergence of the long-forgotten Roman conubium in the spirit and content of the Nuremberg racial laws on marriage and procreation” (Urbanik, 2014: 957).

${ }_{19}$ Here, Urbanik mentions Schulz $(1936,1951)$ and d'Ors (1997), the former regarding that feature of Roman marriage as an expression of humanitas, and the latter the 'pagan mentality' irreconcilable with the Christian approach to marriage. For a view of Roman and Christian values as complementaries (with the former bringing relative peace and order into an individualistic world that continues to fall short of the ideals represented by the latter), see Lombardi Vallauri (1985: 353-354).
} 
of the authors discussed in the previous section. Romanists' ideologies, for Urbanik, work independently of the epistemic status of their reconstruction of Roman legal history. It is, therefore, not their falsehood but their justificatory function that makes them ideologies. Moreover, these ideologies are independent of historical research also in the sense that they come first: Roman law is used only as an example that supports a view grounded in insights not (or at least not necessarily) related to it. Both Waldstein and Urbanik could make their argument in favour of the existence and validity of natural law and judicial activism, respectively, without any reference to Roman law.

We have seen, then, two different concepts of ideology being used by Romanists to explain the interpretive moves of other Romanists. Yet it seems that, in both cases, something more would be needed for a complete explanation. The way the Tellegens describe the interpretive practice of certain scholars corresponds to the concept of 'ideology as false consciousness'. Where they fail to convince, however, is in establishing a link between the opposition of jurists and orators, and the Romanists' efforts to preserve their function within the system of legal education. As just argued, Urbanik's more functionalist (cf. Pines, 1993: 68) approach to the concept of ideology does not require any link between a specific ideology and Roman law. Moreover, his main claim is not about ideologies, as he only writes that the study of Roman law should not be made to serve any ideology. One is nevertheless left wondering how Roman law could fulfil such a role. While that question is perhaps better directed to Waldstein's work, which Urbanik criticises, it also concerns the usefulness of teaching Roman law, which he does affirm. For even if one accepts that studying Roman law makes one a better lawyer, that does not in itself grant Roman law a place in the legal curriculum. ${ }^{20}$ In short, the question of relevance needs to be answered here as well. In the following paragraphs, a possible answer will be outlined with the help of the concept of identity.

\section{Shaping Identities}

Roman law, we are often told, is at the root of European culture, alongside the Bible and the works of Greek philosophy. In many countries, even the emergence of national legal systems took place with constant reference to Roman law (cf., e.g., Wieacker, 1981: 257). Thus, in many countries, Roman law can be regarded as a symbol of both national and European identity. But does that make it relevant for legal education? It may have been the case in certain periods and in certain countries, yet even if such is true,

${ }^{20}$ The same applies to the more detailed argument of Thomas (1998). 
it may still be more reasonable to dedicate just one chapter in the Legal History syllabus to it, as it happens in several countries today. Moreover, to begin with the Tellegens' claim, that kind of national or cultural identity cannot in itself explain why German Romanists would need the separation of jurists and orators. It seems, therefore, that the missing link is rather the lawyers' professional identity, ${ }^{21}$ based on the assumption that law, being a specific object of knowledge, requires a community of experts to maintain and develop the related body of knowledge. Such an identity would explain why some Romanists interpreted the sources as they did, and it could also be used to argue for maintaining Roman law as part of the curriculum. For if we regard our own legal system as continuous with that of the Romans, then it makes sense, on the one hand, to assume that they, too, needed legal specialists, and to have, on the other hand, a subject in the curriculum devoted entirely to the study of their legal system. One should note, however, that this is a weaker claim than that of the Tellegens, and perhaps a more convincing one, since it does not connect the 'early professionalisation' thesis to the necessity of teaching Roman law in law schools.

As for Urbanik's conclusions concerning the usefulness of Roman law, these seem to be closer to the professional approach, as they are formulated with reference to certain roles specific for lawyers. Here then, the concept of cultural or national identities may help to show, this time from a normative perspective, why Roman law is more suitable to do the job than other possible candidates. While there are several ways in which legal skills can be taught, and many others that can be used to develop professional identity (see, e.g., Alexander, 2011), these may not be capable of strengthening cultural (e.g. European) identity. Objections maybe raised, of course, that using Roman law to instil any specific identity can be a dangerous enterprise. Yet the inclusion of Roman law ('the law of the Romans') as a subject in the curriculum has a comparative advantage over modern legal history ('the history of our law') in this respect. Given that we look at it from a distance, as something that is both ours and not, we are more likely to think critically about it than about our current legal systems, even from the perspective of natural law, if only we can resist the temptation to idealise the object of our study (cf. Watson, 1983:53).

\section{Conclusions}

In this paper, two examples of scholarly debates related to the interpretation of Roman legal sources were examined. What made these debates

${ }^{21}$ See Whitman (1990: 93) on the "professors of Roman law as possessing one of the greatest of the old corporate traditions". 
interesting was the references to the concept of ideology. In the first case, ideology understood as false (or forged) consciousness was the charge made against German Romanists, who allegedly tried to re-establish their own position within academia by arguing for the existence of a specialised legal profession in Republican Rome. In the second case, a naturalist approach to Roman law, and the institution of marriage in particular, was criticised as an ideology (i.e., a framework of interpretation) that may distort one's reading of the ancient sources.

In both cases, the question of relevance has been raised. In the first example, the Tellegens wanted to refute the claim they attributed to the German Romanists, that the study of Roman law was important for lawyers, since their profession originated in Rome. (Their insight, i.e. that legal and rhetorical practices are inherently connected, might also be useful for legal education, but that was beyond the scope of their research.) In the second debate, Urbanik explicitly confronted the issue, trying to offer a different justification for teaching Roman law instead of the natural-law one. He pointed to the adaptiveness of Roman law, in contrast to the immutability of its values (as advocated by Waldstein and others).

A further question underlying these debates, and closely related to the relevance of Roman law, seems to be that of identity. In each account, professional as well as cultural and national identities played a role. When considering a justification for the teaching of Roman law, however, neither seems to yield a convincing argument on its own. Instead, it may be the very ambiguity of our relationship to Roman law, and its presence together with its remoteness, that can afford it a place in the legal curriculum.

Edited by Scott M. Culp

\section{References}

Alexander, Charlotte S. (2011), "Learning to be Lawyers: Professional Identity and the Law School Curriculum”, Maryland Law Review, 72(2), 465-483.

Asmis, Elizabeth (2008), "Cicero on Natural Law and the Laws of the State", Classical Antiquity, 27(1), 1-33.

Costa, Pietro (2007), "Images of Law in Europe: In Search of Shared Traditions", in Antony Molho; Diogo Ramada Curto; Niki Koniordos (eds.), Finding Europe: Discourses on Margins, Communities, Images ca. $13^{\text {th }}-c a .18^{\text {th }}$ Centuries. New York/ Oxford: Berghahn Books, 253-272.

Deli, Gergely (2015), Salus rei publicae als Entscheidungsgrundlage des römischen Privatrechts. Budapest: Medium Pro Educatione. 
Eco, Umberto (1990), I limiti dell'interpretazione. Milano: Bompiani.

El Beheiri, Nadja (2012), Das regimen morum der Zensoren: Die Konstruktion des römischen Gemeinwesens. Berlin: Duncker und Humblot.

Frier, Bruce W. (1985), The Rise of the Roman Jurists: Studies in Cicero's Pro Caecina. Princeton, NJ: Princeton University Press.

Giaro, Tomasz (2005), "Problemi romani e problemi romanistici in tema di matrimonio”, in Zuzanna Służewska; Jakub Urbanik (eds.), Marriage: Ideal, Law, Practice - Proceedings of a Conference Held in Memory of Henryk Kupiszewski. Warsaw: Fundacja im. Rafała Taubenschlaga, 83-110.

Grose Hodge, Humfrey (1927), Cicero, Pro Lege Manilia. Pro Caecina. Pro Cluentio. Pro Rabirio Perduellionis Reo. Cambridge, MA: Harvard University Press.

Jhering, Rudolf von (1894), Entwicklungsgeschichte des römischen Rechts. Leipzig: Breitkopf \& Härtel.

Kelsen, Hans (1963), "Die Grundlagen der Naturrechtslehre”, Österreichische Zeitschrift für Öffentliches Recht, 13, 1-37.

Lombardi Vallauri, Luigi (1985), "Christliches und Romanistisches als Prinzipien Europäischer Rechtsgeschichte”, in Okko Behrends; Malte Diesselhorst; Wulf Eckart Voss (eds.), Römisches Recht in der europäischen Tradition: Symposion aus Anlaß des 75. Geburtstages von Franz Wieacker. Ebelsbach am Main: Rolf Gremer, 339-354.

Manthe, Ulrich (1997), "Ein Sieg der Rhetorik über die Jurisprudenz: der Erbschaftsstreit des Manius Curius - Eine vertane Chance der Rechtspolitik", in Ulrich Manthe; Jürgen von Unger-Sternberg (eds.), Grosse Prozesse der römischen Antike. München: Beck, 74-84.

Maras, Daniele F. (2012), "Scientists Declare the Fibula Praenestina and its Inscription to be Genuine 'Beyond any Reasonable Doubt'”, Etruscan News, 14(1, 20). Accessed on 31.10.2016, at http://ancientstudies.fas.nyu.edu/docs/CP/963/EtruscanNews Vol14_2012_winter.pdf.

Mommsen, Theodor (1933), Römische Geschichte, 3. Berlin: Weidmann $\left[14^{\text {th }}\right.$ ed.; orig. 1889].

Nicosia, Giovanni (1965), Studi sulla "Deiectio", 1. Milano: Giuffrè.

d'Ors, Álvaro (1997), Derecho privado romano. Pamplona: Universidad de Navarra [9 $9^{\text {th }}$ ed.; orig. 1968].

Pines, Christopher L. (1993), Ideology and False Consciousness: Marx and his Historical Progenitors. Albany, NY: State University of New York Press.

Savigny, Friedrich Carl von (1803), Das Recht des Besitzes. Eine civilistische Abhandlung. Giessen: Heyer.

Schermaier, Martin Josef (2000), "Bona fides in Roman Contract Law”, in Reinhard Zimmermann; Simon Whittaker (eds.), Good Faith in European Contract Law. Cambridge: Cambridge University Press, 63-92.

Schiavone, Aldo (2005), Ius: l'invenzione del diritto in Occidente. Torino: Giulio Einaudi. 
Schulz, Fritz (1936), Principles of Roman Law. Oxford: Clarendon. Translated by Marguerite Wolff [orig. 1934].

Schulz, Fritz (1946), History of Roman Legal Science. Oxford: Clarendon.

Schulz, Fritz (1951), Classical Roman Law. Oxford: Clarendon.

Stroh, Wilfried (1975), Taxis und Taktik: Die advokatische Dispositionskunst in Ciceros Gerichtsreden. Stuttgart: Teubner.

Tellegen, Jan Willem (1983), “Oratores, Iurisprudentes, and the 'Causa Curiana'”, Revue internationale des droits de l'antiquité, 30, 293-311.

Tellegen, Jan Willem (1996), "Savigny's System and Cicero's Pro Caecina”, Orbis Iuris Romani, 2, 91-106.

Tellegen, Jan Willem; Tellegen-Couperus, Olga E. (2000), "Law and Rhetoric in the Causa Curiana”, Orbis Iuris Romani, 6, 171-202.

Thomas, Philip J. (1998), “Alternative Paradigm for Roman Law”, Revue internationale des droits de l'antiquité, 45, 647-657.

Thomas, Yan (2011), Les opérations du droit. Paris: Seuil.

Tuori, Kaius (2007), Ancient Roman Lawyers and Modern Legal Ideals: Studies on the Impact of Contemporary Concerns in the Interpretation of Ancient Roman Legal History. Frankfurt am Main: Vittorio Klostermann.

Urbanik, Jakub (2014), "On the Uselessness of it All: The Roman Law of Marriage and Modern Times”, Fundamina, 20(2), 946-960.

Waldstein, Wolfgang (2010), Ins Herz geschrieben: das Naturrecht als Fundament einer menschlichen Gesellschaft. Augsburg: Sankt Ulrich Verlag.

Waldstein, Wolfgang (2012), “The Capacity of the Human Mind to Know Natural Law”, Ave Maria Law Review, 11(1), 175-192.

Watson, Alan (1983), "Roman Slave Law and Romanist Ideology", Phoenix, 37(1), 53-65.

Whitman, James Q. (1990), The Legacy of Roman Law in the German Romantic Era: Historical Vision and Legal Change. Princeton (NJ): Princeton University Press.

Wieacker, Franz (1937a), "Geschichtliche Ausgangspunkte der Ehereform”, Deutsches Recht, 7, 178-184.

Wieacker, Franz (1937b), "Der Stand der Rechtserneuerung auf dem Gebiete des bürgerlichen Rechts”, Deutsche Rechtswissenschaft, 2, 3-27.

Wieacker, Franz (1967), "The Causa Curiana and Contemporary Roman Jurisprudence”, The Irish Jurist, 2, 151-164.

Wieacker, Franz (1981), "The Importance of Roman Law for Western Civilization and Western Legal Thought”, Boston College International \& Comparative Law Review, 4(2), 257-281.

Zimmermann, Reinhard (1996a), The Law of Obligations: Roman Foundations of the Civilian Tradition. Oxford/ New York: Oxford University Press [orig. 1990]. 
Zimmermann, Reinhard (1996b), “Savigny’s Legacy: Legal History, Comparative Law, and the Emergence of a European Legal Science”, Law Quarterly Review, 112, 576-605.

Zimmermann, Reinhard; Whittaker, Simon (eds.) (2000), Good Faith in European Contract Law. Cambridge: Cambridge University Press.

Received on 02.11.2016

Accepted for publication on 25.01.2017

\section{Miklós Könczöl}

Department of Legal Philosophy, Pázmány Péter Catholic University Szentkirályi utca 28-30, 1088 Budapest, Hungary

Contact: konczol.miklos@jak.ppke.hu

\section{A importância do direito romano: um olhar sobre o seu papel e as suas ideologias}

$\mathrm{O}$ artigo examina o discurso de historiadores do direito sobre as fontes jurídicas romanas. Para tal, analisa dois exemplos de debates académicos: um relativo ao uso do direito romano enquanto doutrina jurídica intemporal e outro no qual o direito romano surge como uma manifestação histórica do direito natural. O texto concentra-se nos diferentes usos do conceito de 'ideologia' e nos papéis possíveis do direito romano para o ensino do direito. Defende que o conceito de identidade pode contribuir de forma significativa para o entendimento que temos sobre estes debates, bem como para o estudo do direito romano em geral. Palavras-chave: direito natural; direito romano; identidade; ideologia; profissão jurídica.

\section{La pertinence du droit romain: un regard sur ses rôles et ses idéologies}

L'article examine les discours des historiens juridiques concernant l'interprétation des sources juridiques romaines. Il le fait en analysant deux exemples de débats académiques: l'un sur l'utilisation du droit romain comme une doctrine juridique atemporelle, et un autre dans lequel le droit romain apparaît comme une manifestation historique du droit naturel. L'accent est mis sur les différentes utilisations du concept d'idéologie et les rôles possibles du droit romain dans l'éducation juridique. On prétend que la notion d'identité peut contribuer de façon significative à la compréhension de ces débats ainsi qu'à l'étude du droit romain en général.

Mots-clés: droit naturel; droit romain; identité; idéologie; profession juridique. 
